\title{
PERLINDUNGAN HUKUM TERHADAP KORBAN TINDAK PIDANA PEMERKOSAAN DALAM PERADILAN PIDANA
}

\author{
Edy Suwito', Mulyadi Aribowo ${ }^{2}$ \\ 1. Universitas Islam Kadiri, Kediri \\ 2. Pengadilan Negeri Blitar \\ Email: mulyadi aribowo2321@gmail.com
}

\begin{abstract}
This study aims to determine the extent to which legal protection and obstacles faced against the victims of rape in criminal justice in Blitar district court. The context of legal protection against victims of crime (criminal act of rape) is by preventive or repressive efforts conducted by both society and law enforcement officers such as providing protection from various threats that can endanger the life of the victim.

The research used is juridical normative and juridical empirical research. Research location in Blitar District Court. The materials used in literature study are data collection through literature study, and field research involves interviewing informant.

Based on the result of the research, the researcher got the answer that, the legal protection against the victims of criminal act of rape in criminal court in Blitar state court still caused many difficulties in settling either at the investigation stage until the victim was present in the court, because the psychic pressure in victims questioned. This of course affects the mental / psychological development of the victims and also affects the law enforcement process itself to bring about a sense of justice for victims and society.

Keywords: Legal Protection, Victim, Rape
\end{abstract}

\section{A. PENDAHULUAN}

Berbagai macam kejahatan banyak berkembang di kalangan masyarakat, Kejahatan sebagai suatu gejala adalah selalu kejahatan dalam masyarakat dan merupakan bagian dari keseluruhan proses-proses sosial produk sejarah dan senantiasa terkait pada proses-proses ekonomi yang begitu mempengaruhi hubungan antar manusia ${ }^{1}$. Akibat dari kejahatan yang terjadi akan ada pihak yang dirugikan secara jasmaniah maupun rohaniah yang disebut korban. Kejahatan yang marak terjadi adalah kejahatan perkosaan. Tindak pidana perkosaan pada umumnya dialami oleh wanita dan hal ini menimbulkan ketakutan bagi wanita dalam menjalani aktivitasnya dan tak jarang laki-laki terutama yang masih anakanak menjadi korbannya. Kerugian yang sering diderita korban akibat suatu peristiwa kejahatan, misalnya fisik, mental, ekonomi, harga diri dan sebagainya ${ }^{2}$. Perkosaan seksual dan berbagai macam perkosaan yang lain adalah suatu perwujudan kurang atau tidak

\footnotetext{
1 Soerjono Soekanto, 1981. Kriminologi Suatu Pengantar, Ghalia Indonesia. Jakarta, h. 118.

${ }^{2}$ Bambang Waluyo, 2012. Viktimologi Perlindungan Korban dan Saksi, Sinar Grafika, Jakarta, h. 18.
}

adanya rasa tanggungjawab seseorang terhadap sesama manusia ${ }^{3}$.

Dalam suatu peradilan pidana, pihakpihak yang berperan adalah penuntut umum, hakim, terdakwa, dan penasihat hukum serta saksi-saksi. Pihak korban diwakili oleh penuntut umum dan untuk menguatkan pembuktian lazimnya yang bersangkutan dijadikan saksi (korban). Seringkali penuntut umum tidak merasa mewakili kepentingan korban dan bertindak sesuai kemauannya, sehingga kewajiban perlindungan serta hakhak korban diabaikan. ${ }^{4}$

Untuk pengertian umum dari korban seperti tertuang dalam Undang-Undang Nomor 13 Tahun 2006.5 Dalam Undangundang ini dikatakan bahwa korban diberikan perlindungan dalam semua tahap proses peradilan pidana dalam lingkungan peradilan melalui Lembaga Perlindungan saksi atau lembaga sejenis lainnya yang diamanatkan melalui Undang-Undang.

\footnotetext{
${ }^{3}$ Arif Gosita, 198. Relevansi Viktimologi Dengan Pelayanan Terbadap Para Korban Perkosaan Beberapa Catatan. Indhill Co, Jakarta. h. 12.

4 Waluyo, Bambang. (2011). Viktimologi (Perlindungan Korban dan Saksi). Jakarta: Sinar Grafika, p. 8.

Ibid., p. 10.
} 
Pentingnya korban memperoleh pemulihan sebagai upaya menyeimbangkan kondisi korban yang mengalami gangguan, dengan tepat dikemukakan oleh Muladi saat menyatakan: korban kejahatan perlu dilindungi karena pertama, masyarakat dianggap sebagai suatu wujud sistem kepercayaan yang melembaga (system of institutionalized trust). Kedua, adanya argument kontrak sosial dan solidaritas sosial karena boleh dikatakan memonopoli seluruh reaksi sosial terhadap kejahatan dan melarang tindakan-tindakan yang bersifat pribadi. Oleh karena itu, jika terdapat korban kejahatan, maka negara memerhatikan kebutuhan korban dengan cara peningkatan pelayanan maupun pengaturan hak. Ketiga, perlindungan korban yang biasanya dikaitkan dengan salah satu tujuan pemidanaan, yaitu penyelesaian konflik.

\section{B. METODE PENELITIAN}

Dengan suatu metode penelitian diharapkan mampu untuk menemukan, merumuskan, menganalisis, maupun memecahkan suatu masalah dalam penelitian dan agar data yang diperoleh lengkap, diperlukan metode yang tepat yang dapat diandalkan dalam penelitian ini penulis melakukan metode sebagai berikut:

\section{Jenis Penelitian}

Jenis penelitian yang digunakan dalam penulisan tesis ini adalah penelitian bersifat deskriptif menggunakan metode kualitatif dengan pendekatan yuridis sosiologis (social legal approac) $)^{6}$.

\section{Sumber Data}

\section{a. Data Primer}

Data yang bersumber dari pihak-pihak yang terkait secara lansung dengan permasalahan yang diteliti. Data primer dalam penelitian ini diperoleh langsung penulis dari pihak-pihak yang terkait dengan permasalahan yang diangkat.

b. Data Sekunder

1) Bahan hukum primer yang meliputi:

a) Peraturan Perundang-undangan:

1. Undang-undang No. 7 Tahun 1984 tentang Pengesahan mengenai konvensi penghapusan

${ }^{6}$ Sanapiah Faisal, 1990. Penelitian Kualitatif, Dasardasar dan Aplikasi, Malang: YA3, hal. 22 segala bentuk kekerasan terhadap wanita.

2. Undang-Undang No. 13 Tahun 2006 tentang Perlindungan Saksi dan Korban

3. Keppres No. 181 Tahun 1998 Tentang Komisi Nasional Anti Kekerasan Terhadap Perempuan.

4. PP No. 2 Tahun 2002 Tentang tata cara perlidungan terhadap korban dan saksi

2) Bahan Hukum Sekunder

Bahan hukum sekunder yang meliputi literatur-literatur, artikel-artikel dan penjelasan mengenai bahan hukum primer, seperti rancangan undangundang hasil penelitian dan hasil karya dari kalangan hukum.

3) Bahan hukum Tersier

Bahan hukum tersier yaitu bahan yang memberikan petunjuk maupun penjelasan terhadap bahan hukum primer dan bahan hukum sekunder, seperti kamus (hukum), ensiklopedia. ${ }^{7}$

\section{Teknik Pengumpulan Data}

a. Studi Kepustakaan.

Dengan metode ini, permasalahan yang telah dirumuskan dicari teori-teori, konsepsi-konsepsi, pandangan-pandangan yang relevan dengan pokok masalah dari sumber-sumber referensi umum (buku literatur) serta referensi khusus (dokumen). 8

b. Penelitian Lapangan

Penelitian lapangan dalam penelitian ini meliputi: Wawancara, Wawancara merupakan proses tanya jawab secara lisan,antara dua orang atau lebih berhadapan secara langsung,yang kemudian peneliti mengajukan beberapa pertanyaan pada narasumber dari Polisi, Jaksa, Hakim, keluarga terdekat korban.

\section{Teknik Analisis Data}

Dalam analisis data bertujuan untuk mengorganisasikan data-data yang telah diperoleh. Setelah data dari lapangan tekumpul dengan metode pengumpulan data yang telah dijelaskan diatas, maka penulis akan mengelola dan menganalisis data

${ }^{7}$ Ibid, hal. 32.

${ }^{8}$ Soedjono Soekanto, Pengantar Penelitian Hukum, Universitas Indonesia, Jakarta, 2005,Hlm.13 
tersebut dengan menggunakan analisisis deskriptif kualitatif. Analisis data kualitatif adalah upaya yang dilakukan dengan jalan bekerja dengan data, mengorganisasikan data, dan memilah-milahnya menjadi satuan yang dapat dikelola, mensistensikannya, mencari dan menemukan pola, menemukan apa yang penting dan apa yang dipelajari, dan menemukan apa yang dapat diceritakan kepada orang lain.

\section{PEMBAHASAN}

1. Perlindungan Hukum Korban Tindak Pidana Pemerkosaan Dalam Proses Peradilan Pidana

Perlindungan terhadap korban perkosaan membutuhkan partisipasi masyarakat yang berempati terhadap apa yang telah dialaminya, sehingga memenuhi rasa kemanusiaan seperti yang tertuang dalam Pancasila sila ke-2 yang berbunyi, "Kemanusiaan yang adil dan beradab", yang memuat butir-butir nilai kemanusiaan yang adil dan beradab yang antara lain sebagai berikut:

1. Mengakui dan memperlakukan manusia sesuai dengan harkat dan martabatnya sebagai makhluk Tuhan Yang Maha Esa.

2. Mengakui persamaan hak, persamaan derajat dan persamaan kewajiban asasi setiap manusia, tanpa membedakan suku, keturunan, agama, kepercayaan, jenis kelamin, kedudukan sosial, warna kulit dan sebagainya.

3. Mengembangkan sikap saling mencintai sesama manusia.

4. Mengembangkan sikap tenggang rasa dan teposliro.

5. Mengembangkan sikap tidak semenamena terhadap orang lain.

6. Menjunjung tinggi nilai-nilai kemanusiaan.

Dalam konteks perlindungan terhadap korban kejahatan, adanya upaya preventif maupun represif yang dilakukan baik oleh masyarakat maupun pemerintah (melalui aparat penegak hukumnya), seperti pemberian perlindungan/pengawasan dari berbagai ancaman yang dapat membahayakan nyawa korban, pemberian bantuan medis, maupun hukum secara memadai, proses pemeriksaan dan peradilan yang fair terhadap pelaku kejahatan, pada dasarnya merupakan salah satu perwujudan dari perlindungan hak asasi manusia serta instrumen penyeimbang.

Sedangkan secara Represif diperlukan Perlindungan hukum berupa pemberian restitusi dan kompensasi bertujuan mengembalikan kerugian yang dialami oleh korban baik fisik maupun psikis, sebagaimana diatur dalam pasal 98-101 KUHAP. Ada beberapa perlindungan terhadap korban kejahatan yang lazim diberikan, antara lain sebagai berikut:

1. Pemberian Restitusi dan Kompensasi Penjelasan Pasal 35 Undang-Undang Nomor 26 tahun 2000 memberikan pengertian kompensasi, yaitu kerugian yang diberikan oleh negara karena pelaku tidak mampu memberikan ganti kerugian sepenuhnya yang menjadi tanggung jawabnya, sedangkan restitusi, yaitu ganti kerugian yang diberikan kepada korban atau keluarganyaoleh pelaku atau pihak ketiga. ${ }^{9}$

\section{Kendala Yang Di Hadapi Dalam Perlindungan Hak-Hak Korban Tindak Pidana Pemerkosaan}

Kendala yang dihadapi dalam perlindungan hak-hak korban tindak pidana pemerkosaan diantaranya korban merasa malu dan tidak ingin aib yang menimpa dirinya diketahui oleh orang lain, atau korban merasa takut karena telah diancam oleh pelaku bahwa dirinya akan dibunuh. Hal ini tentu saja mempengaruhi perkembangan mental/kejiwaan dari para korban dan juga berpengaruh pada proses penegakan hukum itu sendiri untuk mewujudkan rasa keadilan bagi korban dan masyarakat. Disaat korban dipanggil untuk proses pemerikasaan dan persidangan sering kali tidak mau menghadiri saat diminta memberikan keterangan dan kesaksian disaat terjadinya tindak pidana perkosaan, di karenakan trauma yang dialami setelah kejadian tersebut. Ini menjadi hambatan pihak Penyelidik dan penyidik untuk memperoleh informasi dalam proses penyidikan hingga persidangannya. Namun

\footnotetext{
9 Undang-Undang Nomor 26 Tahun 2000

Tentang Pengadilan Hak Asasi Manusia
} 
disaat pemerikasaan dan sampai di persidangan korban di perlakukan dengan baik agar tidak tertekan Psikologisnya yang mana akan bisa memperlambat proses peradilan. ${ }^{10}$

\section{Upaya Perlindungan Korban Tindak Pidana Perkosaan dalam Sistem Peradilan Pidana di Indonesia}

Fungsi pengadilan selain sebagai pemutus perkara, juga menerima laporan pelaksanaan kompensasi, atau restitusi, mengumumkannya serta memerintahkan instansi atau pihak-pihak untuk melaksanakan putusan dan sebagainya.

Dengan menerapkan sanksi hukum kepada pelaku, maka secara tidak langsung hal itu merupakan suatu bentuk perhatian (perlindungan) secara hukum kepada korban kejahatan. Perlindungan hukum kepada wanita yang menjadi korban kejahatan ini bukan hanya terbatas kepada dihukumnya pelaku, namun juga kepada akibat-akibat yang menimpanya, seperti kehamilan akibat perkosaan. ${ }^{11} \mathrm{Hak}$ atas perlindungan tersebut dapat kita jumpai dalam Pasal 5 ayat (1) UU No. 13 Tahun 2006, yaitu:

a. memperoleh perlindungan atas keamanan pribadi, keluarga, dan harta bendanya, serta bebas dari Ancaman yang berkenaan dengan kesaksian yang akan, sedang, atau telah diberikannya ;

b. ikut serta dalam proses memilih dan menentukan bentuk perlindungan dan dukungan keamanan;

c. memberikan keterangan tanpa tekanan;

d. mendapat penerjemah;

e. bebas dari pertanyaan yang menjerat;

f. mendapatkan informasi mengenai perkembangan kasus;

g. mendapatkan informasi mengenai putusan pengadilan;

h. mengetahui dalam hal terpidana dibebaskan;

${ }^{10}$ Hasil wawancara dengan Ibu Christin, Majelis Hakim Pengadilan Negeri Blitar

${ }^{11}$ Wahid, Abdul dan Irfan, Muhammad. (2001). Perlindungan Terbadap Korban Kekerasan Seksual (Advokasi atas Hak Asasi Perempuan). Bandung: PT Refika Aditama, p. 96. i. mendapat identitas baru;

j. mendapatkan tempat kediaman baru;

k. memperoleh penggantian biaya transportasi sesuai dengan kebutuhan;

1. mendapat nasihat hukum; dan/atau

m. memperoleh bantuan biaya hidup sementara sampai batas waktu perlindungan berakhir.

Dalam penyelesaian kasus perkosaan di pengadilan, perlindungan terhadap korban diupayakan sebagai cara untuk mengurangi beban yang diderita korban. Untuk tidak menambahkan rasa malu serta beban psikis lainnya dalam pengadilan, tindak pidana perkosaan sebagaimana yang diatur dalam Kitab Undang-Undang Hukum Acara Pidana (KUHAP) Pasal 153 ayat (3), untuk perkara kesusilaan hakim dapat menyatakan bahwa sidang tidak terbuka untuk umum (sidang tertutup). Tentunya hal tersebut dapat meringankan beban bagi korban serta secara tidak langsung dapat membantu penyelesaian suatu perkara pemerkosaan melalui bantuan kesaksian korban. ${ }^{12}$

Di dalam KUHAP, korban yang dijadikan sebagai saksi pun diberikan perlindungan dalam pasal 162 KUHAP. Dikatakan sebagai bentuk perlindungan dan penghormatan korban, bahkan dimungkinkkan untuk tidak memberikan kesaksian di persidangan, kesaksiannya dapat dibacakan dari BAP yang ada. KUHAP juga memberi jalan bagi korban (menjadi saksi) untuk mengjajukan tuntutan ganti kerugian (pasal 98 ayat (1) KUHAP).13

Perlindungan korban dalam sistem peradilan pidana dilakukan mulai dari tahap penyelidikan dimulai dan berakhir sebagaimana yang ditentukan oleh UU No.13 Tahun 2006. Perlindungan tersebut dilakukan melalui LPSK sebagai lembaga yang diberikan mandat oleh UU ini. Dalam pasal $12 \mathrm{UU}$ No.13 Tahun 2006 menjelaskan bahwa

12 Lihat Republik Indonesia, Undang-Undang Nomor 8 Tahun 1981 tentang Kitab UndangUndang Hukum Acara Pidana pasal 160 ayat (1) huruf $b$.

${ }^{13}$ Bambang Waluyo, Op. Cit., p. 24-27. 
LPSK bertanggung jawab untuk menangani pemberian perlindungan dan bantuan pada Saksi dan Korban berdasarkan tugas dan kewenangan sebagaimana diatur dalam UndangUndang ini. Perlindungan tersebut membeikan hak kepada korban melalui LPSK sebagaimana yang dituangkan dalam pasal 7 UU No. 13 Tahun 2006 yaitu sebagai berikut:

1) Korban melalui LPSK berhak mengajukan ke pengadilan berupa:

a. hak atas kompensasi dalam kasus pelanggaran hak asasi manusia yang berat;

b. hak atas restitusi atau ganti kerugian yang menjadi tanggung jawab pelaku tindak pidana.

2) Keputusan mengenai kompensasi dan restitusi diberikan oleh pengadilan.

3) Ketentuan lebih lanjut mengenai pemberian kompensasi dan restitusi diatur dengan Peraturan Pemerintah.

\section{KESIMPULAN}

1. Perlindungan hukum korban tindak pidana pemerkosaan dalam proses peradilan pidana dilakukan dengan cara preventif dan represif yang dilakukan oleh masyarakat dan pemerintah. Perlindungan hukum berupa pemberian restitusi dan kompensasi bertujuan mengembalikan kerugian yang dialami oleh korban baik fisik maupun psikis, sebagaimana diatur dalam pasal 98-101 KUHAP.

2. Kendala yang dihadapi dalam perlindungan hak-hak korban tindak pidana perkosaan diantaranya, korban merasa malu dan tidak ingin aib yang menimpa dirinya diketahui oleh orang lain, atau korban merasa takut karena telah diancam oleh pelaku bahwa dirinya akan dibunuh.

3. Upaya perlindungan hukum terhadap korban tindak pidana pemerkosaan dalam sistem Peradilan Pidana di Indonesia diatur dalam:

1) Undang-Undang Nomor 8 Tahun 1981 Tentang Kitab Undang-Undang Hukum Acara Pidana;
2) Undang-Undang Nomor 13 Tahun 2006 Tentang Perlindungan Saksi dan Korban;

3) Undang-Undang Nomor 48 Tahun 2009 Tentang Kekuasaan Kehakiman;

4) Peraturan Pemerintah Nomor 61 Tahun 2014 tentang Kesehatan Reproduksi.

Bentuk perlindungan yang diberikan kepada korban tindak pidana perkosaan mulai dari tahap penyelidikan yang dilakukan melalui PSK dengan diberikannya hak-hak korban berupa tindakan medis dan psikologis sebagai upaya pemulihan kondisi korban, peradilan yang tertutup, kesaksian korban yang dapat dilakukan di luar pengadilan (melalui BAP) sampai pada proses pemulihan berlanjut apabila korban tersebut hamil akibat perkosaan.

\section{E. DAFTAR PUSTAKA}

Abidin. F, Zainal, 2010, Hukum Pidana I, Jakarta: PT. Sinar Grafika

Arif Gosita. 2004. Bunga Rampai Viktimisasi, Bandung, PT. Eresco.

1987. Relevansi Viktimologi Dengan Pelayanan Terbadap Para Korban Perkosaan (Beberapa Catatan), (Jakarta, IND.HILL-CO, 1987),

Harahap, Yahya, 1993. Pembahasan Permasalaban dan Penerapan KUHAP, Jakarta: Pustaka Kartini.

I.S. Susanto, 1995. Kriminologi, (Semarang, Fakultas Hukum UNDIP,)

Lamintang.P.A.F. 1997. Dasar-Dasar Hukum Pidana Indonesia. Bandung: PT. Citra Aditya Bakti.

Marpaung, Leden, 1991. Unsur-unsur Perbuatan Yang Dapat Dibukum (Delik). Jakarta: Sinar Grafika.

Undang-Undang Nomor 8 Tahun 1981 Tentang Kitab Undang-Undang Hukum Acara Pidana;

Undang-Undang Nomor 13 Tahun 2006 Tentang Perlindungan Saksi dan Korban; 